NEWS, VIEWS AND COMMENTS

\title{
Twin Research and the Arts: Interconnections / Twin Research: Twin Studies of Sexual Orientation; A Historical Biological Twin Gem; GWAS Approach to Who Has Twins / Newsworthy: Twins on College Campuses; 'Brainprint': Personal Identification by Brain Waves
}

\author{
Nancy L. Segal \\ Department of Psychology, California State University, Fullerton, CA, USA
}

The interrelatedness between twin research and the arts is explored via a new play about a famous case. In the 1960s, identical twin David Bruce Reimer was accidentally castrated as an infant during circumcision to correct a urinary problem. The decision to raise him as a girl, and the consequences of that decision, are explored in the new theatrical production of Boy. Other examples of the arts mirroring science, and vice versa, are described. Next, brief reviews and summaries of twin research on sexual orientation, 1860s' knowledge of placental arrangements and twinning mechanisms, and genes underlying multiple birth conception and fertility related measures are provided. This article concludes with a look at twins on college campuses and the identification of individuals by their brain waves. A correction and clarification regarding my article on the Brazilian Twin Registry in the last issue of THG (Segal, 2016) is also provided.

\section{Twin Research and the Arts: Interconnections}

The dramatic rise in twinning rates in Western nations, from approximately 1 in 60 births in 1980 to approximately 1 in 30 births in 2014, is well known (Martin et al., 2015). The increased frequency of twins in Western populations and the increased dissemination of findings in both scientific and popular sources have captured the imagination of writers and artists, as well as families and physicians. An interesting question is: which comes first - the scientific study or the creative work? While it is not possible to survey every example of art mirroring science, and vice versa, it is possible to identify examples of both.

As I wrote in my first book, Entwined Lives (Segal, 2000), Professor Thomas J. Bouchard, Jr. and I surveyed scientific journals to find the first occurrence of reared-apart twins. Surprisingly, this design did not originate with Sir
Francis Galton, but was first applied by Paul Popenoe in his landmark case study of separated MZ twins, Bessie and Jessie (Popenoe, 1922). However, we discovered that the Roman comic dramatist, Plautus (254-184 BC) is responsible for the first mention of reared-apart twins, which occurred in his play, Menachemi. This was another surprise, given the likely choice of William Shakespeare, the father of male-female twins, Hamnet and Judith, as the originator of reared-apart twins in drama. Shakespeare authored two plays involving separated twins, namely

ADDRESS FOR CORRESPONDENCE: Nancy L. Segal, Department of Psychology, California State University, Fullerton, CA 92834, USA.E-mail: nsegal@fullerton.edu 
Comedy of Errors (1594) and Twelfth Night (1623). However, his ideas and themes in Comedy of Errors - twins' separation and reunion, and the confusion of twin masters and twin servants - have been ascribed to Plautus's plays, Menachemi and Amphitruo, respectively (Internet Shakespeare Editions, 2011).

Other examples of interconnections between twin research and the arts consist of several insightful dramatic works on human reproductive cloning. They include Slide Glide the Slippery Slope by Kia Corthron (2001), A Number by Caryl Churchill (2014), and Replica by identical twins Janna and Julie Cardia (2014). I have seen all three plays. Replica was especially compelling because the Cardia twins (who are also actresses) played the parts of the cloned individual and the 'original. The musical Side Show (1997), which told the story of conjoined twins Violet and Daisy Hilton, enjoyed a Broadway revival in 2014.

Twins and twin themes have also been featured prominently in the visual arts. The 'reciprocity between religion, media, and medicine' during the Renaissance has been described by Blickstein (2000, p. 187). In a Twin Research article about the conjoined male-female twins of Löwen, he informs us that these twins were featured on a handbill, a not uncommon occurrence of that time. Many 16th-century artists portrayed conjoined twins, working from descriptions rather than actual human models, and produced highly accurate renditions. The possibility that a male-female pair was etched in error has been raised, but not resolved. This debate recalls controversies (still ongoing) over whether fission or fusion is responsible for zygotic connections (i.e., conjoined twins).

In the area of the visual arts, I also want to mention an event in which I recently participated, titled Science and Cocktails, held in Copenhagen, Denmark, on May 7, 2016. Invitees deliver a lecture, followed by a cocktail hour and musical performance. During my talk, Henrik Schütze, an artist and grandfather of twins, stood at his easel painting an artistic work based on my lecture. The result was an intriguing portrayal of the DNA shared by genetically identical twins.

The latest example of the association between scientific work on twins and artistic creation is Boy, a play by Anna Ziegler. Boy, nominated for the 2015-16 John Glassner Playwriting Award, is based on the true events of a famous twin case (Outer Critics Circle, 2016). The case concerned identical Canadian twin David Bruce Reimer and his brother Brian who, as young infants in 1966, were referred for circumcision to correct a urinary problem. David, then Bruce, suffered a tragic medical mistake - ablation of his genitals due to malfunctioning of the surgical equipment that was used (Colapinto, 2001). His parents had no options for treating their infant son until they learned about Johns Hopkins University physician Dr John Money and the work he was doing with intersex babies. Money, believing that gender identity was malleable in early childhood, advised the family to alter Bruce's sex from male to female by means of corrective surgery and hormone therapy. (The decision to transform Bruce into a girl was implemented when he was 17 months of age [Money, 1975]). Bruce and Brian presented an ideal case for assessing the success of such treatment, given the genetic control presented by Brian.

The family followed Dr Money's advice, transforming their son Bruce into their daughter Brenda. The 'experiment' was a dismal failure in the eyes of the twins' family and teachers who could personally witness Brenda's struggle to acquire a female gender role that was completely at odds with her male identity. However, based on the twins' annual visits to Dr Money, Brenda's progress was described in the scientific literature as very successful. Nevertheless, some researchers, particularly Dr Milton Diamond from the University of Hawaii, questioned Money's reports. Diamond eventually tracked down one of the team members who had worked with Brenda, psychiatrist Dr Keith Sigmundson, who was witness to the extreme failure of Money's intervention, but who had remained silent. Diamond and Sigmundson (1997) authored an illuminating paper exposing this case for what it was. According to playwright Anna Ziegler (personal communication, April 16, 2016), an early draft of her play included a character based on Diamond (Ziegler, 2016).

The twins' story has an unfortunate finish. Both Brian and David (who changed gender at age 14 years upon learning the truth) took their own lives in 2002 at age 35 years and at 2004 at age 38 years, respectively.

In April 2016, the play was staged at New York City's Clurman Theater, directed by Lindsay Firman. I have not seen Boy, which was well reviewed in the journal Science (Vikbladh, 2016). Boy touches on a number of broad themes such as the motivations of physicians who take risks with their patients (e.g., using novel equipment as was the case with the surgeon who performed Bruce Reimer's circumcision when he was an infant) and how doctors confront the consequences. The story and the play also remind us that gender identity has significant biological components so is not easily changeable as Money had put forth, and as Diamond continued to challenge.

Correction and Clarification of a THG article describing the Brazilian Twin Registry. Segal, N.L. (2016). Brazilian Twin Registry: A bright future for twin studies. Twin Research and Human Genetics, 19(3), 292-296.

The Brazilian Twin Registry (BTR) is located at the Federal University of Minas Gerais (UFMG). The University of São Paulo is establishing studies with twins under the direction of Dr. Emma Otta. There will be future collaborations between researchers from these two universities with respect to the recruitment of twins and other research activities. Most recently, Dr. Otta visited the BTR in Minas Gervais and attended the twins festival with the support of UFMG. 


\section{Twin Research}

\section{Twin Studies of Sexual Orientation}

An excellent 2016 review of findings and controversies surrounding the origins of sexual orientation includes an informative section on twin studies (Bailey et al., 2016). A critical distinction is made between studies that used targeted sampling and those that used probability (registry) sampling. Targeted sampling refers to identifying participants because they are non-heterosexual, via newsletters, advertising, or similar means. This technique is likely to introduce bias into the results because (1) discordant pairs may be unlikely to take part, and (2) concordant pairs are more likely to be located and to agree to participate. Such studies will, consequently, yield inflated estimates of heritability. Such biases are generally avoided with the use of registry data, because the sample is gathered without reference to the behavior of interest.

The different findings between studies that used the two approaches to data collection are illustrative. Median correlations across studies yielded correlations of 0.52 (MZ) and 0.17 (DZ) for studies using targeted sampling. In contrast, the median correlations were 0.25 (MZ) and 0.13 (DZ) for studies using registry data. Heritability is decidedly less (0.32) when calculated from registry data. Interestingly, an Australian twin registry study by Kirk et al. (2000; not included in the Bailey et al., 2016 summary) reported heritabilities of 0.30 for male sexual orientation and between $0.50-0.60$ for female sexual orientation. The 4,901 twins in this study answered an anonymous questionnaire, which may have increased the truthfulness of their responses. Note that the relatively higher heritabilities reported for females than males in the Australian study are at odds with the more frequent findings of relatively higher male than female heritability, such as those from a large registry-based Swedish investigation (males: 0.34-0.39; females: 0.18-19.) by Långström et al. (2010). Bailey et al. (2016) noted that calculating the degree of genetic and environmental effects on sexual orientation separately for males and females was precluded by the availability of too few registry samples. Such an analysis should be possible in the future, given the growing number of twin registries worldwide (Hur \& Craig, 2013; Segal, 2016).

Bailey et al. (2016) concluded that sexual orientation has a genetic basis, but has non-genetic components, as well. Some non-genetic influences may be prenatal, whereas another concerns birth order - male homosexuals tend to have a greater number of older brothers than do heterosexual men, heterosexual women, and homosexual women. These effects are distinct from social environmental influences (e.g., seduction by an older same-sex individual or rearing by homosexual parents) that have been incorrectly identified for triggering homosexual tendencies.

This article is introduced by thoughtful commentary from Savin-Williams (2016), Professor of Human Development at Cornell University (and a former fellow graduate student of mine at the University of Chicago).

\section{An Historical Biological Twin Gem}

While researching existing information on twinning mechanisms, I came across a fascinating review paper authored in the mid-1800s by Spaeth (1862). Spaeth was a professor of obstetrics in Vienna. He provides detailed descriptions of placentas, choria, and amnia among the twins he delivered. Among his 125 cases, he discovered:

1. 48 pairs with two placentae, two choria, and two amnia (38.4\%);

2. 46 pairs with fused (united) placenta, two choria, and two amnia $(36.8 \%)$;

3. 28 pairs with fused (united) placenta, one chorion, and two amnia (22.4\%);

4. two pairs with fused (united) placenta, one chorion, and one amnion (1.6\%).

The relatively high percentage of twins with two chorions and two amnions most likely reflects the fact that both $\mathrm{MZ}$ and DZ twin pairs were combined in his analysis. (Of course, the distinction between twin types had not been established in 1862.) However, the percentage of twin pairs with one chorion and one amnion (1.6\%) agrees with what current researchers find among MZ twins.

Spaeth also addressed questions regarding superfecundation and superfetation - what he termed 'afterconception'. In both cases, the second ovum is fertilized after the first - days in the case of superfecundation, and weeks in the case of superfetation. He poses the question of whether sexual intercourse must be repeated for these events to occur. He answers his own question by stating that the different degrees of development between the twins would suggest that more than one act of intercourse would be required. He is correct, except that superfecundated twins conceived several days apart would be unlikely to show marked developmental discrepancies.

This paper is worth reading for appreciating what was known about twinning 150 years ago, and the kinds of questions that were asked that have taken us to where we are today. 


\section{GWAS Approach to who has DZ Twins}

A 2016 study that gathered data from mothers of twins in the Netherlands, Australia, and the United States found two genes that increased the $\mathrm{DZ}$ twinning risk from 10.7/1,000 (the frequency in the Dutch population) to $12.71 / 1,000$ if all females had two copies of both genes (Mbarek et al., 2016). These results were then validated using an Icelandic population. This is the first such study to examine this ques- tion this way. The two genetic variants, FSHB and SMAD3, are also associated with other reproductive and health characteristics, such as age at menarche, age at first child, lifetime parity, risk of polycystic ovarian syndrome (PCOS), and age at menopause. Extending such analyses to populations known for extremely high and extremely low DZ twinning rates - for example, Benin and Japan, respectively - would be an important research undertaking in the future.

\section{Newsworthy}

\section{Twins on College Campuses}

The May 16, 2016 issue of the Harvard Gazette delved into the lives of four of the 15 pairs of twins among their undergraduates (Chase, 2016). Harvard's class of 2019, admitted as freshman in fall 2015, includes 1,660 students (Harvard University, 2016). Assuming equal enrollment across all 4 years yields a total of 6,640 students, with twins representing $30 / 6,640$ or $0.45 \%$ of the student body. This figure is low, relative to the $3.3 \%$ of twins in the general population; however, it does not include twins who attend Harvard University without their co-twins.

The pairs who are profiled offer exciting ideas about what variables could potentially be studied among twin college students. Anna and Anne Raheem plan to focus on bioengineering, with a possible minor in government, international relations, or language. They are described as fraternal, but appear identical in some photographs. Identical twins Alex and Eli Lee have different interests in Central Asian languages (Eli) and drawing and film (Alex). They did not plan to attend college together, but do not regret their situation. These twins enjoy having one another easily accessible, but do not spend all their time together. Alannah and Grace O'Brien, who appear to be identical, have not yet chosen a major, but Grace is considering government. Nicholas and Beau Bayh look quite different from one another, but their interests align. Both twins are interested in politics, social service, and athletics. Their grandfather Birch Bayh served as United States senator, and their father Evan Bayh served as both governor and United States Senator from Indiana.

Colleges and universities are rich sources of young adult twins, a largely understudied segment of the twin population. Similarities in decisions regarding choice of schools, campus residences, and majors have never been formally compared between identical and fraternal twin pairs (Segal, 2014). Establishing national registries of twins enrolled in higher education programs would facilitate such studies.

\section{'Brainprint': Personal Identification by Brain Waves}

Sarah Lazlo and colleagues from the State University of New York (SUNY) at Binghamton have developed a system for individual identification, based on brain waves (SUNY Binghamton, 2016). The idea is that when people respond to an extensive series of images they feel differently about them, yielding highly unique neurological responses, or 'brainprints'. An initial study found $97 \%$ accuracy in an attempt to identify one person out of 32 . A subsequent effort with 50 participants who viewed 500 images produced 100\% accuracy. This work has implications for highsecurity clearance at places like the United States Pentagon.

As I reviewed this article, I wondered if the technology would be able to distinguish between identical twins. Given the large number of stimuli it is likely that some response differences would emerge, but this would nevertheless be interesting to determine. It is known that dermatoglyphic characteristics are not identical between identical co-twins, so one twin cannot substitute for the other in a crime scene. However, given that identical co-twins think alike and process information similarly, it is at least conceivable that one twin's brainprint could match, or closely match, that of the other.

The initial study is reported in Armstrong et al. (2015). The second study that showed $100 \%$ accuracy in personal identification is awaiting publication (Ruiz-Blondet et al., 2016).

\section{References}

Armstrong, B. C., Ruiz-Blondet, M., Khalifian, N., Jin, Z., Kurtz, K. J., \& Laszlo, S. (2015). Brainprint: Assessing the uniqueness, collectability, and permanence of a novel method for ERP biometrics. Neurocomputing, 166, 59-67.

Bailey, J. M., Vasey, P. L., Diamond, L. M., Breedlove, S. M., Vilain, E., \& Epprecht, M. (2016). Sexual orientation, controversy and science. Psychological Science in the Public Interest, 17, 45-101. 
Blickstein, I. (2000). The conjoined twins of Löwen. Twin Research, 3, 185-188.

Chase, J. (2016). Doubling up at harvard. Harvard Gazette. Retrieved from http://news.harvard.edu/gazette/story/2016/ 05/doubling - up-at-harvard

Colapinto, J. (2001). As nature made him: The boy who was raised as a girl. New York: Harper Perennial.

Diamond, M., \& Sigmundson, H. K. (1997). Sex reassignment at birth: Long-term review and clinical implications. Archives of Pediatrics and Adolescent Medicine, 151, 298304.

Harvard University. (2016). Admissions statistics. Retrieved from https://college.harvard.edu/admissions/ admissions-statistics

Hur, Y.-M., \& Craig, J. M. (2013). Twin registries worldwide: An important resource for scientific research. Twin Research and Human Genetics, 16, 1-12.

Internet Shakespeare Editions. (2011). Shakespeare and Plautus. Retrieved from http://internetshakespeare.uvic.ca/ Library/SLT/drama/classical\%20drama/plautus.html

Kirk, K. M., Bailey, J. M., Dunne, M. P., \& Martin, N. G. (2000). Measurement models for sexual orientation in a community twin sample. Behavior Genetics, 30, 345-356.

Långström, N., Rahman, Q., Carlström, E., \& Lichtenstein, P. (2010). Genetic and environmental effects on same-sex sexual behavior: A population study of twins in Sweden. Archives of Sexual Behavior, 39, 75-80.

Martin, J. A., Hamilton, B. E., Osterman, M. J. K., Curtin, S. C., \& Matthews, T. J. (2015). Births: Final data for 2013. National Vital Statistics Reports, 64, 1-68.

Mbarek, H., Steinberg, S., Nyholt, D. R., Gordon, S. D., Miller, M. B., McRae, A. F., ... Davies, G. E. (2016). Identification of common genetic variants influencing spontaneous dizygotic twinning and female fertility. The American Journal of Human Genetics, 98, 898-908

Money, J. (1975). Ablatio penis: normal male infant sexreassigned as a girl. Archives of Sexual Behavior, 4(1), 6571.

Outer Critics Circle. (2016). Awards for 2015-2016. Retrieved from http://outercritics.org/award-results/ awards-for-2015-2016/

Popenoe, P. (1922). Twins reared apart. Journal of Heredity, 13, $142-144$.

Ruiz-Blondet, M., Jin, Z., \& Laszlo, S. (2016). Cerebre: A novel method for very high accuracy event-related potential biometric identification. IEEE Transactions on Information Forensics and Security, 11, 1618-1629

Savin-Williams, R. (2016). Sexual orientation: Categories or continuum? Commentary on Bailey et al. (2016). Psychological Science in the Public Interest, 17, 37-44.

Segal, N. L. (2000). Entwined lives: Twins and what they tell us about human behavior. New York: Plume.

Segal, N. L. (2014). College-age twins: University admissions policies. Twin Research and Human Genetics, 17, 594598.

Segal, N. L. (2016). Brazilian Twin Registry: A bright future for twin studies. Twin Research and Human Genetics, 19, 292296.

Spaeth, J. (1862). Studies regarding twins. Edinburgh Medical Journal, 7, 841-849.

SUNY Binghamton. (2016, April 18). Researchers can identify you by your brain waves with $100 \%$ accuracy. Science Daily. Retrieved from https://www.sciencedaily.com/ releases/2016/04/160418120608.htm

Vikbladh, O. (2016). Identity theft. Science, 352, 46.

Ziegler, A. (2016, 13 April). Personal communication. 